\title{
Two portraits of Agrippa Postumus in the British Museum
}

\author{
Miles Russell ${ }^{1}$ (D), and Harry Manley² \\ ${ }^{1}$ Department of Archaeology and Anthropology, Bournemouth University \\ $<$ mrussell@bournemouth.ac.uk> \\ ${ }^{2}$ Department of Life and Environmental Sciences, Bournemouth University \\ $<$ hmanley@bournemouth.ac.uk>
}

\begin{abstract}
Two damaged and partially restored Roman portraits in the collection of the British Museum, previously identified as either the emperor Caligula or an unknown "Julio-Claudian prince," are here reassessed and identified as Agrippa Postumus, the youngest grandson and adopted heir of Augustus. The first portrait, from southern Britain, may have come from a temple dedicated to the worship of the Julio-Claudian house, while the second was probably part of an equestrian group standing outside the Aedes Castoris in Rome. This is a significant reinterpretation, providing potential evidence not only for links between Rome's first family and the rulers of a distant client kingdom, but also for the framing of imperial power and the uncertain nature of the Augustan succession in the early years of the 1 st c. CE.
\end{abstract}

Keywords: Agrippa Postumus, Augustus, Julio-Claudian portraiture, British Museum, Dioscuri

A large quantity of Greek and Roman sculpture today exists in the museums and private collections of northwestern Europe, most having been acquired during the 17th and 18th c. Frequently deprived of context or date, many statues languish in a form of academic limbo, their identity and significance unknown. Worse, few such items survive in anything like their original condition, often having been aggressively cleaned or "repaired" through the application of new or alternative elements. As a result, it is frequently difficult to establish the original look of a particular sculpture, let alone identify which body parts belonged to which statue. ${ }^{1}$ Two examples of repaired Roman sculpture in the British Museum, for which the provenance and identity are far from clear, are considered in this article. One is a portrait bust found in Broadbridge in southern Britain in the mid-19th c.; the other is part of an equestrian statue group found in Rome in 1864. Although different in intent and provenance, the two images are indisputably of the same individual.

\section{Portrait bust from Broadbridge}

The life-size head of a young man (Fig. 1), in a white, gray-veined Italian marble, was acquired by the British Museum in $1961 .^{2}$ The circumstances surrounding discovery are unfortunately vague: in a letter dated 1910, K. H. MacDermott noted that the artifact had been unearthed 50 or 60 years earlier, during the cutting of house foundations near the old mill at Broadbridge in West Sussex, England. ${ }^{3}$ At the time of reporting, the head was part of a garden rockery, where it stood in a flowerpot. ${ }^{4}$ Sold to a local archaeologist, Edward Heron-Allen, in 1911, it was extensively cleaned, restored, and mounted in a

Fejfer 1997, 3-8.

$2 \quad$ British Museum Acc. 1961,1103.1: Painter 1965, 180.

3 MacDermott, quoted in Painter 1965, 179.

$4 \quad$ MacDermott 1910; MacDermott, quoted in Painter 1965, 179-80. 

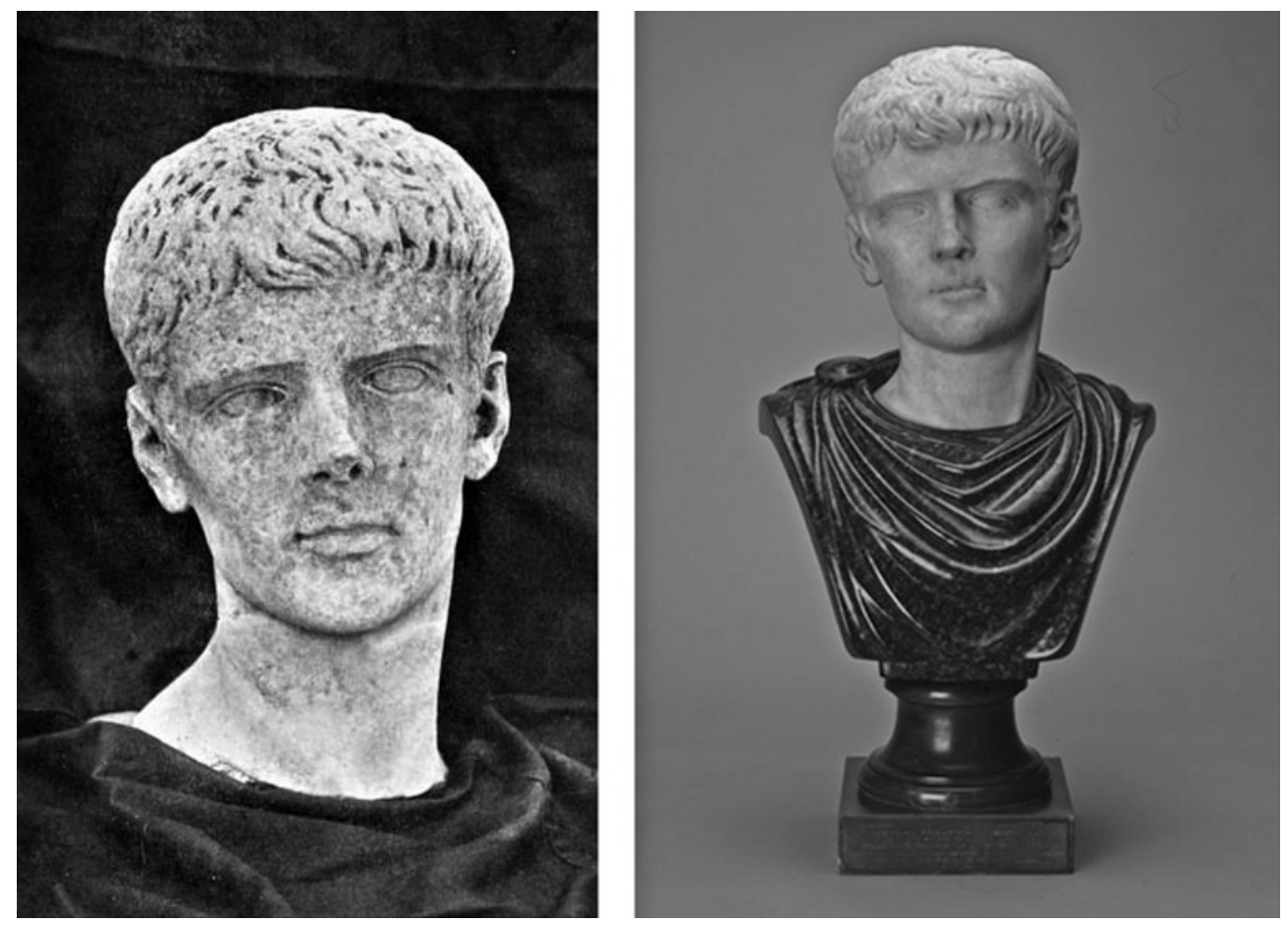

Fig. 1. The Broadbridge head: (a) photographed in 1909 (C Sussex Archaeological Society) and (b) in 2009 (@) Trustees of the British Museum, inv. no. 1961,1103.1).

modern green marble bust. ${ }^{5}$ Following Heron-Allen's death in 1943, the portrait came into the possession of Captain A. W. F. Fuller, who allowed the British Museum to purchase it. ${ }^{6}$

Although the head is Roman in design, lack of clarity concerning its original findspot, combined with the crisp appearance of the face, has led to doubts as to its authenticity. ${ }^{7}$ Since acquiring the artifact, the British Museum has been reluctant to put it on permanent display, the general consensus being that it was perhaps an ancient object imported from the Mediterranean by an early antiquarian collector and subsequently discarded. ${ }^{8} \mathrm{~A}$ copper plate, fixed to the bust (possibly by Heron-Allen) states:

Contemporary portrait bust of a member of the CLAUDIAN FAMILY probably GERMANICUS. Found (c 1840) on the traditional site of a VILLA of VESPASIAN at BOSHAM SUSSEX. Probably not Romano-British BUT IMPORTED IN THE EARLY XVIII CENTURY

Painter wondered whether the head was of 17 th-c. manufacture, possibly one of a number of classically inspired pieces generated by Italian sculptors for the tourist market. ${ }^{9}$ Soffe and Henig, however, studying photographs taken in 1909, felt that, given the condition of

MacDermott, quoted in Painter 1965, 179-80; Heron-Allen 1915.

Painter 1971, 8; Soffe and Henig 1999, 8; Langhorne 2014, 8.

Cunliffe and Fulford 1982, 23.

Toynbee 1962, 123; Painter 1971, 37.

Painter 1971, 37; see Fittschen 2006, 162-74, for a discussion and comparison of ancient and modern copies. 
the head prior to restoration, there were no grounds for thinking it was anything other than a genuine antiquity. ${ }^{10}$

\section{Description}

In an attempt to better record the precise form of the portrait, resolve issues surrounding authenticity and identity, and provide a better understanding of carving, reworking, and damage, a three-dimensional, $360^{\circ}$ scan of the head was conducted with a tripodmounted Konica Minolta VI900 laser scanner. The head was mounted on a rotating turntable set $0.6 \mathrm{~m}$ from the scanner and, using the Triangulation Light Block method, a laser-generated beam was deflected from a rotating mirror onto the surface, the beam being reflected back and focused through a series of lenses onto a sensor. Using a middle-range lens with a focal length of $14 \mathrm{~mm}$, a field of view of ca. $0.4 \times 0.3 \mathrm{~m}$ was achieved. The portrait was then rotated incrementally until a total of 55 overlapping scan point clouds were collected. Each scan had a laser point separation of $\sim 0.5 \mathrm{~mm}$ and a point accuracy of $\pm 0.05 \mathrm{~mm}$. The individual point clouds were rendered to create a mesh representing the 3D surface of the portrait. Overlapping points in adjacent scans were then used to create a composite object. Five images taken from the 3D scan are reproduced here (Fig. 2).

Measuring $0.3 \mathrm{~m}$ in height and $0.18 \mathrm{~m}$ in width, the portrait is a realistic depiction of a clean-shaven young man in the round. It is in excellent condition, having suffered only minor damage to the nose (repaired) and ears. At some point, probably in the early 20th c., the neck was set into a supporting bust of green marble, something which today creates an aura of 18th-c. facsimile. ${ }^{11}$ The facial features are more crisply defined than the hair, the curls of which have a weathered appearance, suggesting that the face was aggressively cleaned following discovery in the mid-19th c. This probably occurred during the ownership of Edward Heron-Allen, between 1911 and 1943, as photographs of the head, taken in 1909 by the British Museum, show the facial features to be less well defined. ${ }^{12}$ Despite extensive cleaning, some traces of the original tool marks remain at the line between hair and skin and lightly around the eyes, the presence of which, together with the overall weathered form of the coiffure, serve to confirm Soffe and Henig's observations regarding the antiquity of the piece. ${ }^{13}$

The head is inclined slightly to the right with eyes downward. The lightly pitted cheeks are hollowed, defining a firm jaw with a small, pointed chin and well-rounded, slightly parted lips, upper lip protruding. Close-set, almond-shaped, thinly lidded eyes are set beneath sharply defined, gently curving brows and a straight nose, the damaged tip of which was replaced in the 20th c. The delicately layered cap of hair is arranged in a series of long, thick, comma-shaped locks, combed forward from the crown, creating a short fringe above a smooth forehead, with sideburns curling over both ears toward the face. The fringe comprises a complex series of locks, combed inwards from both corners of the forehead. There is a small, V-shaped parting above the center of the portrait's right eye. To the right of this, two comma-shaped locks curl right, while to the left, three longer

Soffe and Henig 1999, 37.

MacDermott 1910, 272 and pl. 25; Painter 1965, 178.

Soffe and Henig 1999, 8; Langhorne 2014, 8.

Soffe and Henig 1999, 37. 
Miles Russell and Harry Manley
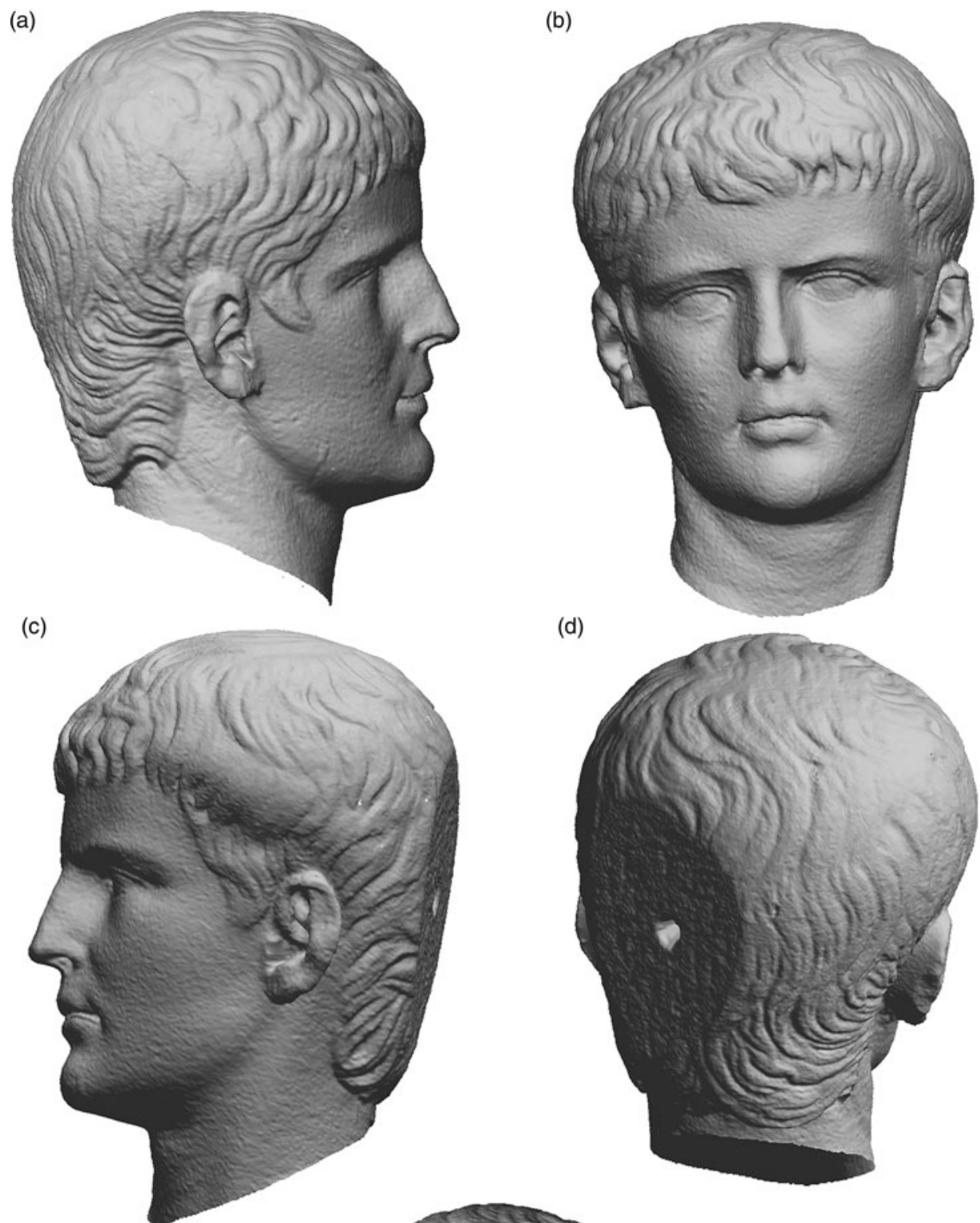

(d)

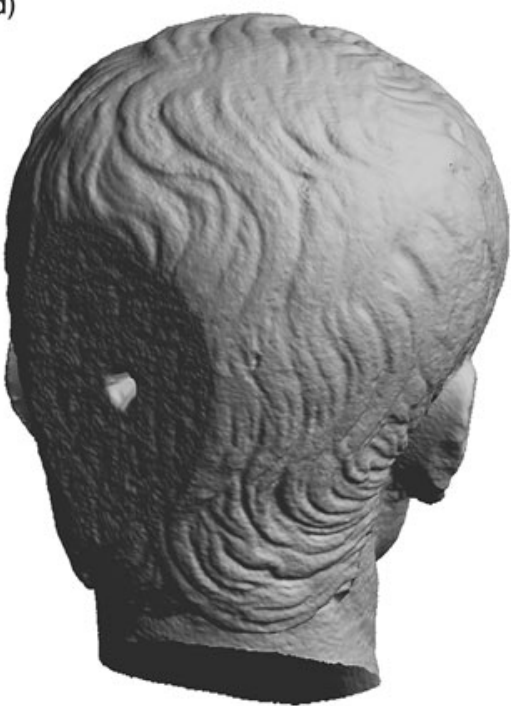

(e)

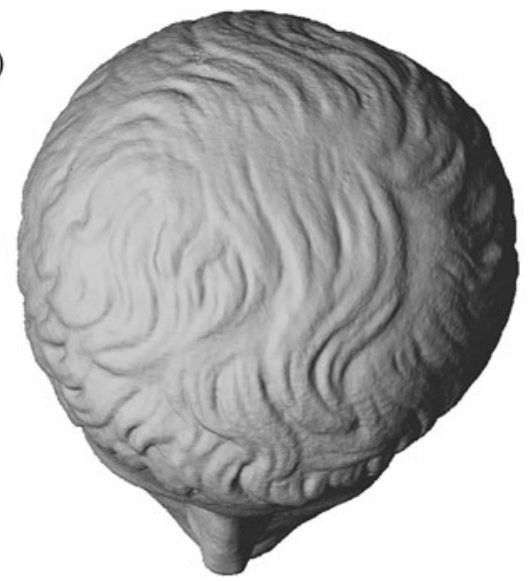

Fig. 2. 3D scan of the Broadbridge head: (a) right profile; (b) front view; (c) left profile; (d) back view; (e) top. (C) Bournemouth University.) 
locks turn left, finishing just above the start of the portrait's left eye. The locks on the right side of the head are fulsome and livelier than those on the left, which are lackluster, limp, and more deeply incised, something which may relate to later, less competent reworking or cleaning. The hair is long at the neck and combed sharply forward in two prominent waves, the curls on the right again appearing more delicate and lightly incised than those on the left.

An addition to the back of the Broadbridge head was removed by the British Museum in 1961, leaving the flattened, lightly picked surface with a round dowel hole that we see today. ${ }^{14}$ The stone patch appears to have been an ancient augmentation to the portrait, unlike the more modern repair to the nose or the green marble bust. ${ }^{15}$ MacDermott thought that the head had been "intentionally flattened at the back as though it had been against a wall."16 Alternatively, and perhaps more probably, the flattened surface reflects a shortage of marble at the time of manufacture. ${ }^{17}$ Lack of suitable raw material in the Roman world occasionally led to "the custom of constructing portrait heads from two pieces of marble or, better, from one piece of marble later augmented," dimpled incisions and/or a dowel ensuring that another piece of stone, or more malleable material, such as a plaster or stucco, could be added, completing the overall look of the portrait. ${ }^{18}$ A similar feature can be seen on a mid-1st-c. CE marble head of a young man recovered during the excavations at Fishbourne, $3.4 \mathrm{~km}$ to the east of Broadbridge Mill. ${ }^{19}$ As Connor noted, the nature of the worked surface and patch on the Broadbridge head strongly attest to both the antiquity and authenticity of the piece, "fashioned, as it is, after a common Roman technique." 20

\section{Identification}

When the piece was first reported to the British Museum, Frederick Marshall, assistant keeper of Greek and Roman antiquities, thought it was "not improbably Germanicus," son of Nero Claudius Drusus and Antonia the Younger, the daughter of Augustus's sister Octavia. ${ }^{21}$ Jocelyn Toynbee dated the Broadbridge head to the very early days of the Empire, also suggesting that it was most likely a representation of Germanicus, an interpretation that has generally stuck. ${ }^{22}$ The Broadbridge face, however, is too thin for Germanicus, especially with regard to the deep-set eyes and structure of the cheekbones, which stand in marked contrast to the rather fleshy portraits of him that survive today, while the coiffure does not correspond at all with his three main portrait types. ${ }^{23}$ Other writers have suggested that the head could depict Caligula (Gaius), son of Germanicus

Connor 1974, 379.

Contra Heron-Allen 1915, 217.

Quoted in Painter 1965, 179.

Soffe and Henig 1999, 9.

Connor 1974, 379; Padgett 2001, 22.

Russell and Manley 2013, 3.3.1.

Connor 1974, 380.

MacDermott 1910, 272.

Toynbee 1962, 123; Soffe and Henig 1999, 8-9.

For example: Fittschen 1986; Boschung 1993, 59-61; Johansen 1994, 126-33; Rose 1997, 64-65;

Giroire and Roger 2007, 76. 
and Augustus's granddaughter Agrippina the Elder, or perhaps another Julio-Claudian prince, possibly Gaius or Lucius, older grandsons of Augustus via his only child, Julia, and her husband, Marcus Agrippa. ${ }^{24}$

The difficulties in identifying individual members of the Julio-Claudian family from surviving portraiture are well known. ${ }^{25}$ The replicas of the men, in particular, emphasize youthful characteristics and are similar in physiognomy, presenting broad regularity in facial features, with large eyes, sharp brows, and strong noses. Portraits of Caligula are particularly difficult to identify, partly because his reign was so short, with no opportunity to create or develop a distinctive typology, but also because busts of him were removed or defaced after his assassination, there being no subsequent period of rehabilitation. ${ }^{26}$ Worse, from the perspective of identification, portraits of Caligula's father, Germanicus, and his uncles Gaius and Lucius, often appear as commemorative, postmortem images, idealizing otherwise distinctive aspects of the face. ${ }^{27}$ Male Julio-Claudian hair-stylings are generally depicted in a similar way, with boyish, delicately curled, thick-set layered hair. ${ }^{28}$ Often, the only real distinction between individual portraits can be found in the differential arrangement of curls in the fringe, a feature which, despite potential difficulties in capturing facial distinctiveness, could easily have been replicated by a sculptor, helping an audience to identify the subject. ${ }^{29}$

The methodology by which individuals are identified on the basis of the number, position, and arrangement of sculptured forehead locks, although not without limitations, has successfully been deployed in order to categorize and classify a number of Julio-Claudian portraits. ${ }^{30}$ The styling of the fringe across the forehead in the Broadbridge portrait is not seen in the known portraits of Germanicus, Gaius, Lucius, or Caligula, but it does correspond precisely with what Zanker, Fittschen, and Boschung have all convincingly identified as the second of two portrait types established for Agrippa Postumus, best exemplified in images currently curated in the Musei Capitolini, the Galleria degli Uffizi, and the Musée du Louvre (Fig. 3). ${ }^{31}$ The matching of forehead locks in the Broadbridge portrait with the Uffizi and Louvre examples confirms that the Broadbridge head also commemorated Agrippa Postumus, being an example of his second major portrait type, a more serious, post-adoption image probably inaugurated in $4 \mathrm{CE} .{ }^{32}$

Marcus Vipsanius Agrippa Postumus was the fifth child of Marcus Agrippa and Julia the Elder, the daughter of Augustus. Born in 12 BCE, shortly after the death of his father, Postumus was later adopted by his grandfather as joint heir, alongside Tiberius, son of

24 Painter 1971, 36-37; Connor 1974, 381; Cunliffe and Fulford 1982, 23.

$25 \quad$ Kleiner 1992, 123-41; Boschung 1993.

26 Kleiner 1992, 126; Boschung 1993; Pollini 2020; Varner 2004, 23-42; Calomino 2016, 53-58.

27 Kleiner 1992, 72-75.

28 Kleiner 1992, 63.

$29 \quad$ Boschung 1993; Pollini 1987, 9; Pollini 2020, 75.

30 On the Lockenzählmethode, see Pollini 1987, 9-10; Boschung 1993.

31 Zanker 1973, 185; Fittschen 1977, 40; Boschung 1993, 55-56; Musei Capitolini, inv. no. 422; Fittschen and Zanker 1985, no. 21; Galleria degli Uffizi, inv. no. 1914.113; Musée du Louvre, inv. no. MA 3498; Giroire and Roger 2007, 72.

32 Classified as Type 16 Capitoline Gladiatori: Fittschen and Zanker 1985, no. 21; Boschung 1993, 55; Grigoire and Roger 2007, 72. 
(a)

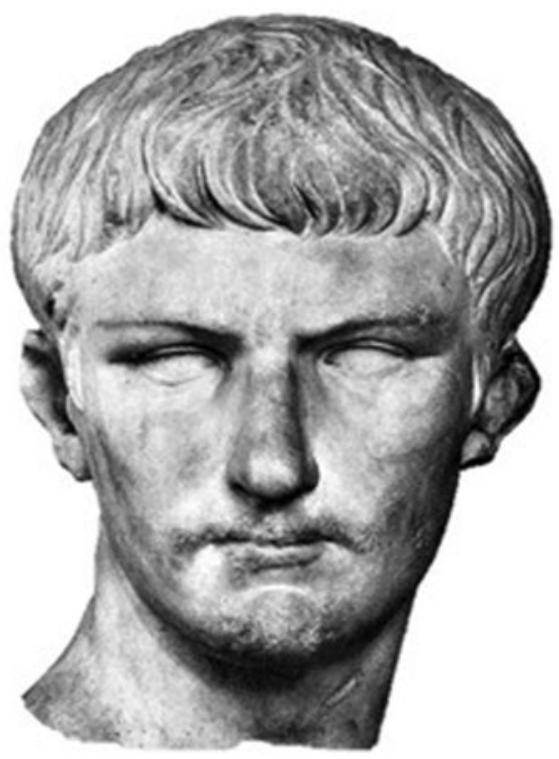

(c)

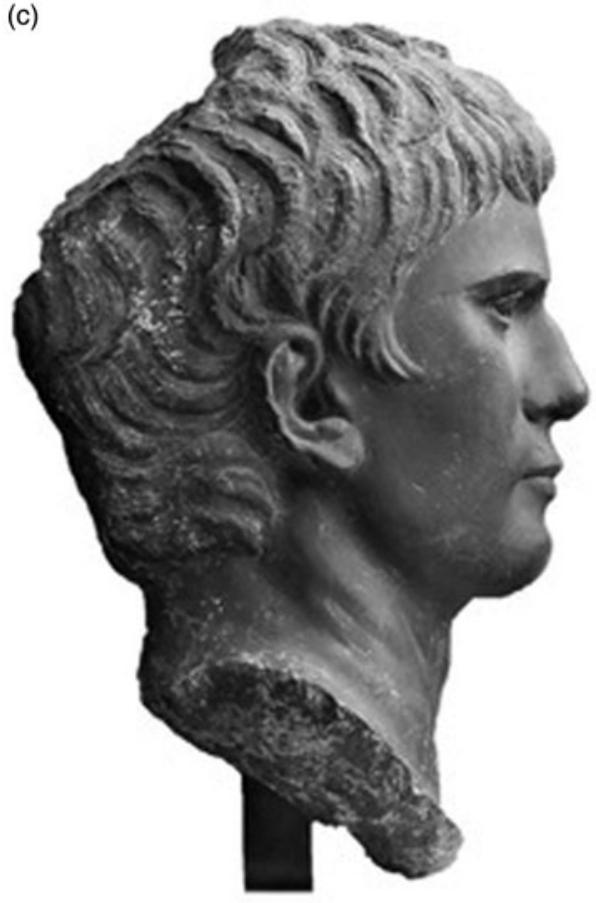

(b)

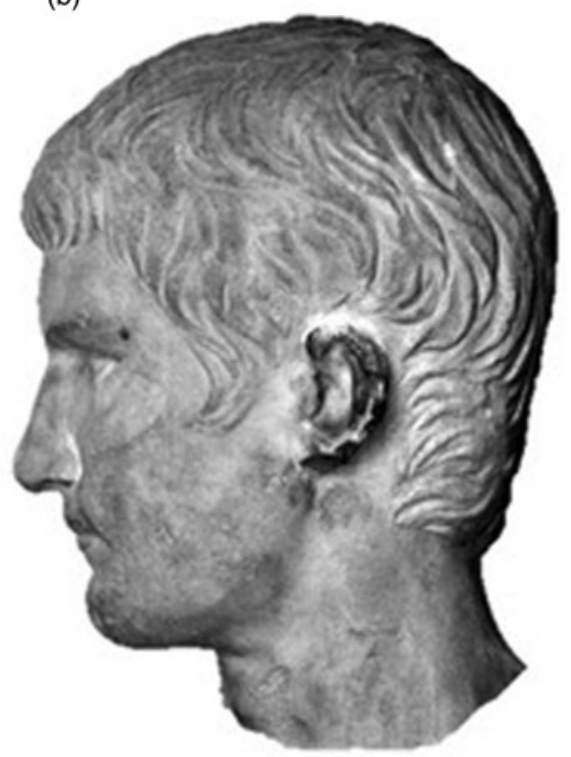

(d)

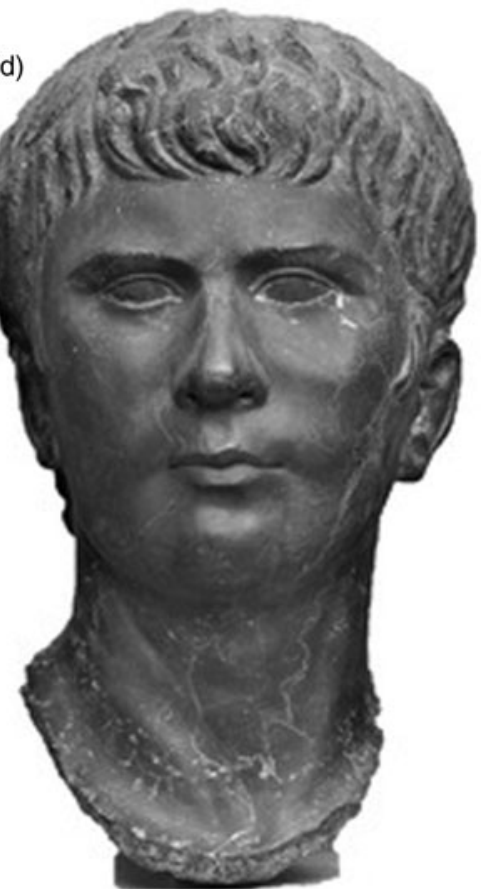

Fig. 3. Portraits identified as Agrippa Postumus in Rome: (a) front view, (b) left profile (@ Musei Capitolini, inv. no. 422); and in Paris: (c) right profile, (d) front view (@) Musée du Louvre, inv. no. MA 3498).

Augustus's second wife, Livia Drusilla, from her earlier marriage to Tiberius Claudius Nero. As grandchildren of the princeps, Agrippa Postumus and his siblings - Gaius, Julia (the Younger), Lucius, and Agrippina (the Elder) - formed the essence of Augustus's great dynastic plan. Postumus's elder brothers, Gaius and Lucius, were 
formally adopted by the princeps as heirs in $17 \mathrm{BCE}$, images of both increasingly emulating elements of Augustus's own stylized official portrait, unlike portraits of Postumus, whose features continued to resemble those of his real father. ${ }^{33}$ The untimely deaths of both Lucius and Gaius, in 2 and 4 CE respectively, led Augustus to adopt Postumus, his sole remaining grandson, together with his stepson Tiberius as his new heirs in June $4 \mathrm{CE}$. Postumus was then aged 14; Tiberius was 45.

Taking the name Marcus Julius Caesar Agrippa Postumus, the last grandson of Augustus was recognized as the heir to the princeps's name and property, but not his title and position. The right of succession to Augustus was instead conferred upon Tiberius, who was adopted as full son and heir on condition that he in turn adopt his nephew Germanicus, the son of his brother Drusus and Augustus's niece Antonia Minor, as heir. The honors bestowed on Agrippa Postumus differed considerably from those earlier granted to his brothers, Gaius and Lucius. This may have been due to the increasing influence of Augustus's wife, Livia, the mother of Tiberius, who wished to see her own son advanced. Alternatively, the failure to treat Agrippa Postumus equally may have been due to deficiencies in his character and temperament. ${ }^{34}$

Prior to his exile, the image of Agrippa Postumus, as both blood relative to Augustus and heir to his property, appeared on coins and in sculpture. ${ }^{35}$ The earliest example of portraiture identified, the Newby Hall type, seems to date to before his adoption by Augustus, and is similar in style, physiognomy, and hair-styling to those images created for his elder siblings, Gaius and Lucius. ${ }^{36}$ Following his banishment in $7 \mathrm{CE}$, Postumus was excluded from all imperial group portraits and dedications and, on the death of Augustus in $14 \mathrm{CE}$, he was murdered, possibly on the direct orders of Tiberius. ${ }^{37}$ His memory appears to have been rehabilitated, however, during the reign of his nephew Caligula, perhaps being reclaimed and commemorated not just as a relative but also as a prominent victim of the second princeps, although no additional images of Postumus appear to have been created at this time. ${ }^{38}$

\section{Equestrian statue from Rome}

A heroically posed, life-size equestrian statue, standing to a height of $2.05 \mathrm{~m}$ and carved from white Italian marble (Fig. 4), is today positioned in the south side of the Great Court of the British Museum. ${ }^{39}$ The statue depicts a young man, naked except for a military cloak, sitting astride a muscular horse. The group was retrieved from excavations in Rome, although, like many antique sculptures, context and location were not recorded. Restoration in the late 16th c. by Giacomo della Porta made many repairs to the torso and face of the youth, while his arms and neck, together with three legs of the horse, have been replaced. From 1652, the statue stood within the Palazzo Farnese; it was sold by the King of Naples, Ferdinand II, to the British Museum in $1864 .{ }^{40}$

Zanker 1988, 220.

Suet. Aug. 65.1, 65.4; but see Tac. Ann. 1.3.

Varner 2004, 89.

Boschung 1993, 55.

Varner 2004, 89.

Varner 2004, 89.

British Museum, inv. no. 1864,1021.2.

Smith 1892, 153. 
(a)

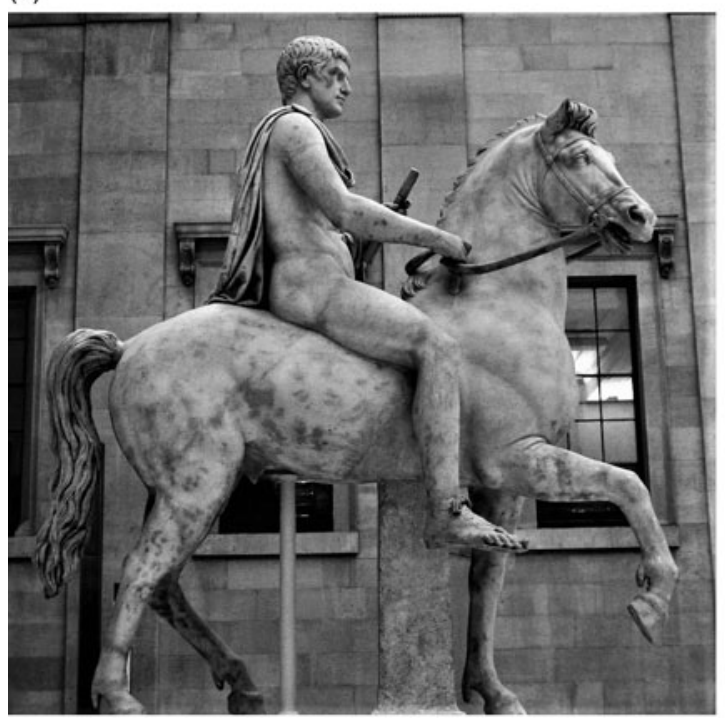

(b)

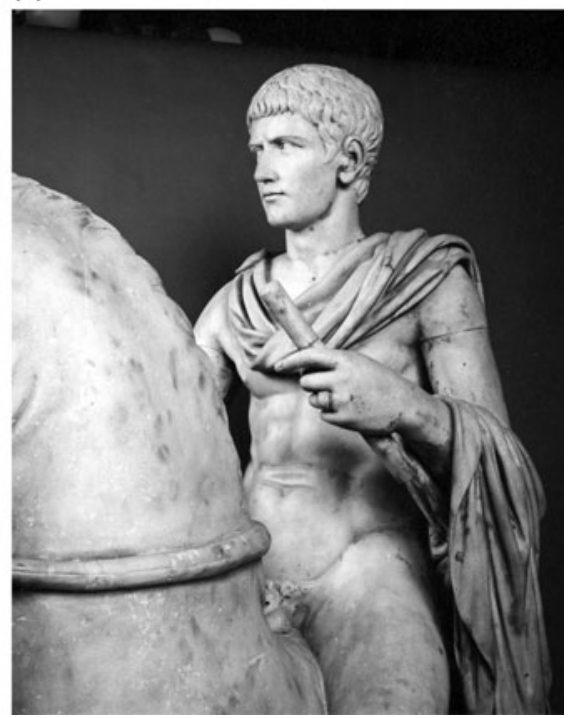

Fig. 4. The equestrian statue of "A Julio-Claudian prince" in the British Museum: (a) right side; (b) left half-profile. (@) Trustees of the British Museum, inv. no. 1864,1021.2.)

\section{Description}

The equestrian statue was studied by the authors at the same time as the Broadbridge bust. Unfortunately, the elevated position of the group, combined with its current setting in the Great Court in the British Museum, meant that it was not possible to access nor safely survey it. Instead, a series of photographs were taken of the head (Fig. 5), in order to directly compare it with the results of the Broadbridge 3D laser scan.

The young man's head is turned slightly to the right, in the direction of his outstretched arm, his gaze directed forward and down. This downcast look, albeit realistic from the perspective of a rider, is unlike most surviving forms of Roman portraiture, especially those representing public servants and important members of state, which usually possess a backward tilt, eyes set horizontally or upward. The modern resetting and repositioning of the head, broken below the level of the jaw, may be a significant factor in this. At one time it was thought that the antique head might be alien to the body, being joined by a modern neck. Recent examination, however, has shown that the head is of the same marble as the unrestored parts of the horse, both the body of the rider and the head itself being in anatomical proportion. ${ }^{41}$ The cloak, fastened on the right shoulder with a large, circular, undecorated brooch, flows over the young man's left shoulder, wrapping itself around the lower left arm. His left (restored) arm holds a scroll; the right gently clasps the reins to steady the horse, much as it probably did in antiquity.

The cheeks are hollowed, defining a firm jaw and a pointed chin. The nose is straight and the lips are well formed and slightly parted, with the upper lip protruding. Almond-shaped, close-set eyes are set beneath gently curving brows. The coiffure is 

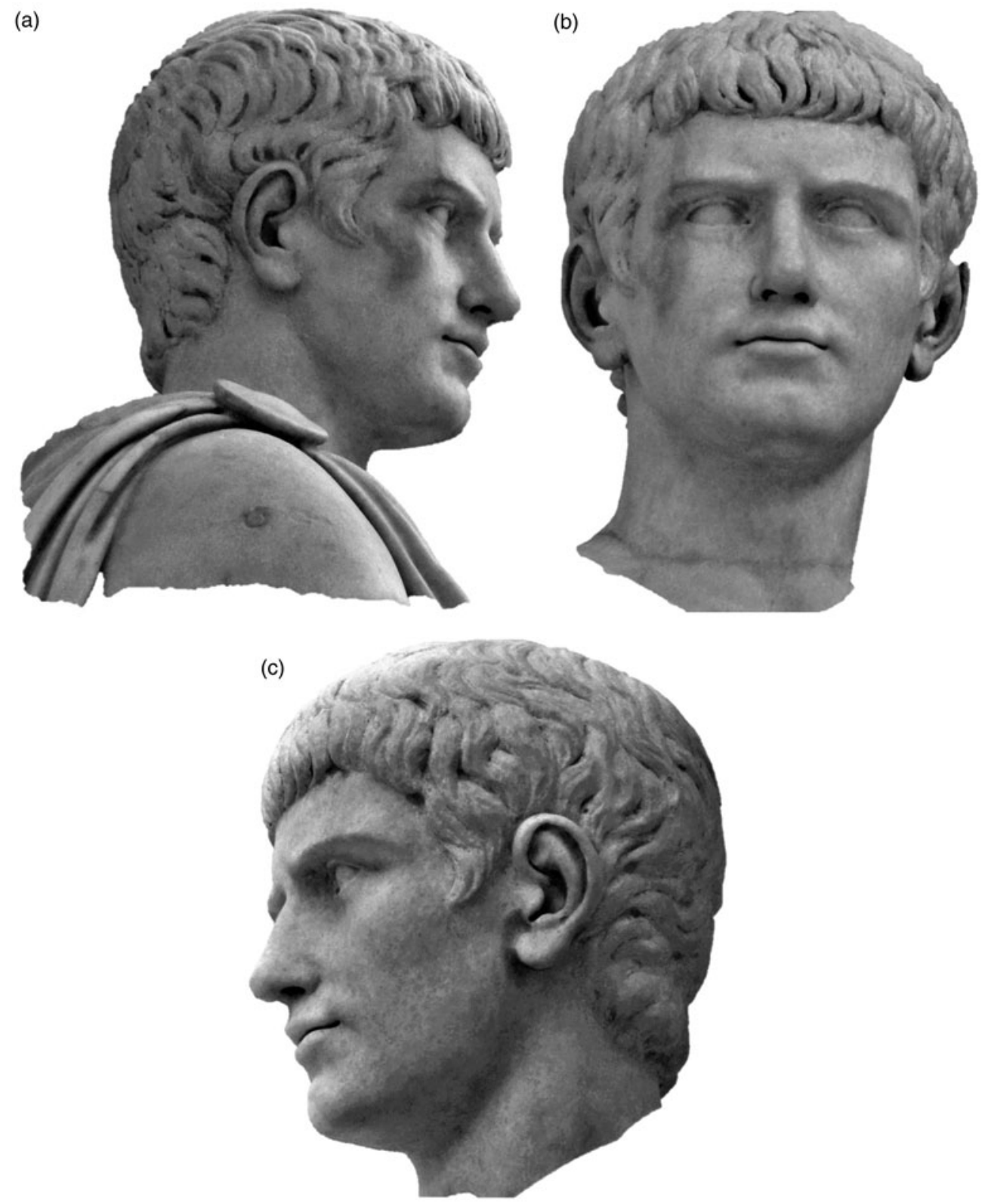

Fig. 5. The portrait head of the British Museum equestrian statue: (a) right profile; (b) front view; (c) left profile. (Photos Miles Russell: British Museum inv. no. 1864,1021.2.)

formed from a layered mop of thick hair, with well-defined, comma-shaped locks worn long at the neck and loosely combed forward from the crown, with sideburns curling over the ears towards the face. A short fringe comprises an intricate set of curls, combed inwards from both corners of the forehead. A small, V-shaped parting sits above the center of the right eye, to the right of which two comma-shaped locks curl right, while to the left, three longer locks turn left, finishing just before the start of the left eye of the portrait, followed by four thinner, comma-shaped locks curling to the right. 


\section{Identification}

When the piece was acquired by the British Museum, it was identified as a "so-called Caligula," an interpretation which has largely stuck. ${ }^{42}$ Smith thought that the equestrian nature of the statue suggested a later emperor, possibly Geta or Alexander Severus, although the semi-idealized facial features and hairstyle fits portraits created for the Julio-Claudian dynasty. ${ }^{43}$ The figure's fringe is a prominent and distinctive badge which, as with the Broadbridge head, clearly identifies the portrait as Agrippa Postumus, being an example of his second major portrait type, the more serious, post-adoption image inaugurated in $4 \mathrm{CE}$.

In addition to the distinctive nature of the fringe, the image itself mirrors the physiognomic peculiarities of the Broadbridge head, as well as portraits of Postumus preserved in the Musei Capitolini, the Galleria degli Uffizi, and the Musée du Louvre, while the gently curving eyebrows replicate those of Postumus's father, Marcus Agrippa, rather than the semi-idealized brows of Gaius and Lucius following their adoption by Augustus. ${ }^{44}$ As a youthful representation of the designated heir to the property and family name of the first princeps, the portrait cannot conceivably date before $4 \mathrm{CE}$ or much beyond $7 \mathrm{CE}$, the year that Postumus was sent into exile. It could conceivably relate to a period of postmortem rehabilitation, such as that suggested as occurring under the rule of Caligula (37-41 CE) and later Claudius (41-54 CE), although it must be said that no additional examples of Postumus commemorated in bronze, marble, or coin at this time have been established.

\section{Discussion}

Portraits of Agrippa Postumus are not rare; the two examples noted here bring the total recorded now to $14 .{ }^{45}$ However, they are extremely important, having been created for the ruling Julio-Claudian dynasty at a time when the future of the Principate hung in the balance. Official replicas of an individual whose time and position at court were limited, and whose exile and death ensured that his image was not widely disseminated, are of major significance, providing evidence of how imperial portraits were created, established, and displayed. In this instance, lack of detailed objective information surrounding the context of discovery for both the equestrian statue from Rome and the Broadbridge bust is somewhat frustrating, although a few key points should be noted.

The nature of the equestrian statue, featuring a young athletic male, naked except for a cloak draped over the shoulders and left arm, strongly recalls the classical image of the Dioskouroi/Dioscuri. Postumus's older brothers, Gaius and Lucius, had been closely linked with Castor and Pollux on coinage, their adoption by Augustus as his heirs on the same day marking them as Caesares Gemini. ${ }^{46}$ In Corinth, two marble statues from the Julian Basilica provide further evidence of the direct association between the heirs of Augustus

42 Smith 1892, 153; Russell 2006, 215.

43 Smith 1892, 153.

44 Musei Capitolini, inv. no. 422; Galleria degli Uffizi, inv. no. 1914.113; Musée du Louvre, inv. no. MA 3498; Zanker 1988, 219-20.

45 Boschung 1993, 54-56; Giroire and Roger 2007, 72.

46 Polini 1987, 20. 
and the Dioscuri, Gaius and Lucius being depicted in semi-idealized form, naked with only a mantle draped over their left shoulders. ${ }^{47}$

As princeps, Augustus occupied a unique position and was naturally concerned that the succession of his title and powers be handled with care, the concept of a hereditary monarchy being anathema to the Republic. To this end, he and his followers skillfully appropriated mythology, history, and memory for their own purposes, successfully exploiting all aspects of Republican art and architecture. One monument woven into the new ideology was the Aedes Castoris in the Forum Romanum. The use of this temple for public meetings and legislative assemblies made it "resonant of popular sovereignty," while its foundation mythology, which told of the appearance of Castor and Pollux at the Battle of Lake Regillus, made it politically and militarily irresistible. Augustus chose to glorify his own family through the clear identification of his successors with the Dioscuri, the Temple of Castor being the end point of the transvectio equitum, the annual parade of young men of the equestrian class. ${ }^{48}$

The Dioscuri, as "heroes whose achievements in their lifetimes were so grand that they were accorded divine status," were appropriate counterparts for the successors nominated by Augustus. ${ }^{49}$ Not only could Castor and Pollux be considered as gods on Earth, a status to which the Julio-Claudians themselves naturally aspired, but they were also saviors, "the averters of evil," "emblems of future life," and "a paragon of fraternal harmony," unlike Romulus and Remus, whose relationship led to civil war. ${ }^{50}$ So successful was this association that the Dioscuri continued to be equated throughout the Principate with the fraternal harmony of imperial heirs and the peaceful transition of power under dynastic succession. ${ }^{51}$ Even better, from the perspective of Augustus, Pollux was acknowledged as the son of Jupiter, king of the gods and protector of Rome, to whom the spoils of war were ultimately presented. As the adoptive father of Gaius and Lucius/Castor and Pollux, the princeps could ensure that he was subtly equated with Jupiter, or at the very least identified as the primary agent in the service of the divine. ${ }^{52}$

Not only were Gaius and Lucius identified with the Dioscuri on coin and in sculptured relief, but so too were Augustus's later choices for the succession. In $6 \mathrm{CE}$, the Temple of Castor and Pollux was rededicated in the names of his stepsons, Drusus and his brother Tiberius, drawing an additional link between the adopted heirs of the princeps and their divine counterparts. ${ }^{53}$ If the equestrian group in the British Museum was originally one of the two Dioscuri, as the near-naked, youthful, saddleless nature of the figure suggests, then it may originally have formed part of a Julio-Claudian monument erected in Rome to the twins, possibly outside (or close to) the reconstructed and rededicated Temple of Castor and Pollux.

Polini 1987, 19-20.

Sumi 2009, 179-80.

Sumi 2009, 181.

Sumi 2009, 184; Champlin 2011, 74.

Sumi 2009, 185; Pollini 2012, 455-88.

Sumi 2009, 183.

Champlin 2011, 82; Sumi 2009, 184. 
If the current head was part of the original setting, something which cannot be determined with certainty, it would suggest that this was part of a group portraying Augustus's stepson Tiberius and his last surviving grandson, Agrippa Postumus, as Dioscuri, presumably at, or shortly after, their formal adoption as the sons and heirs of the princeps in $4 \mathrm{CE}$. If so, the statue could only have stood unaltered for a maximum of three years, Agrippa Postumus being discredited and sent into exile in 7 CE. This interpretation, although entirely plausible (and favored by the current authors), is, in the absence of any detail surrounding the original context of the statue group, ultimately unprovable.

Concerning the portrait of Agrippa Postumus from Broadbridge in the British Museum, the condition of the head, combined with the vague details surrounding its discovery, has led to suspicions that the artifact is either of 17th-c. date or a Grand Tour import. ${ }^{54}$ There seems little doubt, however, when considering both the weathering patterns of the portrait (especially across the hair, which has been less aggressively cleaned than the face) and the presence of the stone patch augmentation, that the head is of genuine antiquity and not a modern facsimile. ${ }^{55}$ Furthermore, analysis of archaeological material from the area surrounding Broadbridge indicates that the sculpture is probably of genuine Romano-British provenance.

Although a significant amount of Classical Greek and Roman sculpture was exported to Britain (not always legally) from the Mediterranean throughout the 18th and 19th c., there is no evidence for such artwork being discarded in the English countryside. ${ }^{56}$ Busts, statues, inscriptions, and sarcophagi were transported directly to the houses of the wealthy landed gentry, with many pieces remaining on display in country estates such as Petworth, Wilton, or Hever Castle, or within museums to which they were later sold or donated. Having gone to the effort of locating, paying for, and importing sculptural material to Britain, it would seem strange that any self-respecting 18th-c. dilettante would have mislaid valuable items of statuary some significant distance from their home. The only examples where Classical sculpture was abandoned were with regard to bankrupted estates of financially or politically discredited landowners, such as at Arundel House in London, or Ince Blundell Hall, Merseyside. ${ }^{57}$

Had the Broadbridge head been the only Roman portrait retrieved from this general area of Britain, one might be forgiven for accepting that it was a modern import. It is, however, one of a number of significant Roman statue fragments recovered within the past 300 years from this particular part of England. At the church of the Holy Trinity in Bosham, $1.7 \mathrm{~km}$ southwest of Broadbridge Mill, a twice-life-size marble head, found sometime before 1782, has been identified as a posthumous portrait of the emperor Trajan. $^{58}$ A life-size stone fragment of a cuirassed figure (almost certainly an emperor in military attire) and a life-size bronze thumb have also been identified from the area. ${ }^{59}$

$54 \quad$ Toynbee 1964, 46; Painter 1971, 37.

55 Soffe and Henig 1999, 8; Fittschen 2006, 162-74.

56 Michaelis 1882; Scott 2003; Bignamini and Hornsby 2010, 99; Russell 2016, 115.

57 Fejfer 1997; Raeder 2000; Vickers 2006, 11-13, 84; Dimas 2013; Stewart 2020.

58 CSIR 1.2, no. 90. Toynbee 1964, 50; Cunliffe and Fulford 1982, 24; Soffe and Henig 1999, 9; Henig 2002, 51; Russell and Manley 2015, 156-60.

59 Soffe and Henig 1999; Henig 2002, 51-54; Kenny 2004; Russell 2006, $216-17$. 
Further afield, at Fishbourne, $2.9 \mathrm{~km}$ to the east, part of a life-size marble statue of a young man, discovered during excavations in the north wing of a late 1st-c. palace, has been identified as a representation of Nero, made in $50 \mathrm{CE}$ at the time of his adoption by Claudius. ${ }^{60}$ Evidence for a second portrait of Nero, from 58/59 CE, has come from Chichester, $5 \mathrm{~km}$ east of Broadbridge Mill, where fragments of an inscribed statue base were found in $1740 .^{61}$ Also from Chichester, two inscriptions - the first to Neptune and Minerva and "the welfare of the divine house," the second, a dedication to Jupiter "in honor of the divine house" testify to the localized celebration of the ruling Roman first family, closely linking imperial patronage with civic identity. ${ }^{62}$ Other, later imperial connections between Sussex and Rome can be determined from a mid-4th-c. portrait of the emperor Julian from Chichester (now in the Princeton University Art Museum), a bronze arm from Halnaker, and a mid-3rd-c. marble bust of the emperor Gallienus from Pulborough. ${ }^{63}$

Together, these multiple fragments, although damaged and divorced from their primary contexts, suggest that the Broadbridge head, far from being an isolated and wholly unusual artifact, was part of a genuine cluster of imperial artwork, indicating a significant degree of Romanitas among the population and civic administration of this part of southern Britain from the 1st until the later 4th c. CE. As an adoption portrait of Agrippa Postumus, the head could only have come to Britain at, or shortly after, $4 \mathrm{CE}$, a time when the political and economic ties between Rome and the local elite were particularly strong. ${ }^{64}$ Alternatively, it could have arrived in Britain during the reigns of Caligula and Claudius, when the character of Postumus was undergoing a degree of rehabilitation. Considering the later prominence given to the "divine house" by elements of the southern British tribal aristocracy here, this latter suggestion is eminently plausible. ${ }^{65}$

A specific context for the Broadbridge head may derive from a series of masonry structures and associated features discovered in the area in the early 19th c. Local tradition ascribes the site of the discovery of a "Villa of Vespasian" (to which the copper plate mentioned above testifies). Although Roman structures and finds have been found at Bosham, Broadbridge, and the surrounding area, there is no evidence of a "villa" per se, although it should be noted that the late 1st-c. palace of Fishbourne lies less than $3 \mathrm{~km}$ to the east. A series of Roman buildings close to Broadbridge Mill, incompletely identified through excavation, include a rectangular stone building, a large structure "in the form of a basin" containing "tiers of seats," at least one mosaic, and a timber palisade. ${ }^{66}$ The vague nature of the original account makes full understanding and interpretation of this site difficult, although there can be little doubt that the main structure described was a temple. ${ }^{67}$ More problematic is the basin-like structure, although the tiered seating sounds like the remains of a small theater, perhaps akin to the rural theater/religious complexes identified

\footnotetext{
$60 \quad$ Cunliffe 1971, 155; Cunliffe and Fulford 1982, 24; Russell and Manley 2013.

61 RIB no. 92; Collingwood and Wright 1965, 26-27; Russell 2006, 72-74.

62 RIB no. 91; RIB no. 89; Collingwood and Wright 1965, 24-25.

63 Padgett 2001, 80-82; Russell 2013; CSIR 1.2, no. 157; Cunliffe and Fulford 1982, 43; Russell 2016;

Russell 2019.

64 Cunliffe 1973; Russell 2006, 55-67.

65 Russell 2006, 33-43.

66 Black 1985, 255.

$67 \quad$ Mitchell 1866.
} 
at Frilford in Oxfordshire and Gosbecks in Essex. ${ }^{68}$ The combination of temple and possible theater at Broadbridge, together with the portrait of at least one member of the imperial family, is highly suggestive of a major cult center. Only further archaeological investigation can determine its full nature.

\section{Conclusions}

The unknown "Julio-Claudian prince" depicted in the form of an equestrian statue and a portrait bust in the British Museum can both now be identified as Marcus Vipsanius Agrippa Postumus, the youngest grandson and one-time adopted heir of the first princeps, Augustus. Although the provenance of both sculptures is vague, it can plausibly be suggested that the life-size portrait from Broadbridge in southern Britain may have originally formed a discrete bust (as now) or have been part of a larger, full-size statue, dislocated from the body following Postumus's fall from political grace in $7 \mathrm{CE}$. As such, it may have entered Britain at a time when native rulers were affirming their loyalty to Augustus in the late 1st c. BCE or early 1st c. CE. Alternatively, the sculpture could have entered Britain during the reign of Claudius, when evidence for the worship of the divine house of the Julio-Claudian family within the local client kingdom may have taken the form of a specially dedicated temple. Whatever the case, there seems little doubt that the head is a genuine antiquity with a Romano-British context, rather than a more modern import.

With regard to the equestrian group originally from Rome, if the head currently fixed to the body was indeed part of the primary design, then this would appear to be a representation of Agrippa Postumus as one of the Dioscuri, presumably Castor (who had a mortal father), which was intended to stand together with a figure of Tiberius, the acknowledged heir of the princeps, cast as Pollux, the son of Jupiter. If so, the statue, in its current form, would probably have been established no earlier than $4 \mathrm{CE}$ and could only have stood until $7 \mathrm{CE}$ before being removed or having its identity realigned ${ }^{69}$ Tiberius certainly understood the value of being linked to potent mythology, the heavenly twins being both talismans of victory and benefactors of humankind. ${ }^{70}$ Throughout his reign, he seems to have continually promoted the link between himself and Pollux the immortal - even to the point of inverting the way in which the Dioscuri were thought of - regularly referring to the Temple of Pollux and Castor. ${ }^{71}$

It is often the neglected artifacts in museums which "serve as the best raw material for future research," while even those objects on prominent display have the capacity to inform and surprise. ${ }^{72}$ Such considerations are true for the two sculptures of Agrippa Postumus described here, neither of which has previously contributed to the archaeo-historical debate. By assigning them an identity, considering their significance, and reassessing their possible context, it is hoped that both will now take their rightful place in discussions, not only about the projection of power and identity within the

68 Burnham and Wacher 1990, 178; Hawkes and Crummy 1995, 178.

${ }_{69}$ Unless it was part of a later attempt to rehabilitate the character of Postumus, for which as yet there is no firm sculptural evidence.

70 Champlin 2011, 90.

71 Champlin 2011, 88.

72 Thompson 2015, 209. 
Julio-Claudian family, but about how the nature of dynastic succession was formulated by Augustus in Rome and then disseminated to the wider population of the distant provinces.

Acknowledgments: We wish to thank Ralph Jackson and Richard Hobbs, curators of the Romano-British collections at the British Museum, and Thorsten Opper, curator of Greek and Roman sculpture, for facilitating the study and 3D scan, as well as for providing much useful discussion and debate throughout. We are also grateful for the helpful comments of the anonymous reviewers.

\section{References}

Bignamini, I., and Hornsby, C. 2010. Digging and Dealing in Eighteenth-Century Rome. New Haven: Yale University Press.

Black, E. 1985. "The Roman buildings at Bosham." Sussex Archaeological Collections 123: 255-56.

Boschung, D. 1993. "Die Bildnistypen der iulisch-claudischen Kaiserfamilie: Ein kritischer Forschungsbericht." JRA 6: 39-79.

Burnham, C., and Wacher, J. 1990. The Small Towns of Roman Britain. London: Batsford.

Calomino, D. 2016. Defacing the Past: Damnation and Desecration in Imperial Rome. London: Spink and the British Museum.

Champlin, E. 2011. "Tiberius and the heavenly twins". JRS 101: 73-99.

Collingwood, R., and R. Wright. 1965. The Roman Inscriptions of Britain. Vol. 1, Inscriptions on Stone. Oxford: Clarendon.

Connor, P. 1974. "A mote on the Broadbridge (Sussex) head." Britannia 5: 379-81.

Cunliffe, B. 1971. Excavations at Fishbourne. Vol. 2, The Finds. London: Society of Antiquaries.

Cunliffe, B. 1973. The Regni. London: Duckworth.

Cunliffe, B., and Fulford, M. 1982. Corpus of Sculpture of the Roman World: Great Britain. Vol. 1, Fasc. 2, Bath and the Rest of Wessex. Oxford: Oxford University Press.

Dimas, S. 2013. Die Antikensammlungen von Hever Castle, Cliveden, Bignor Park und Knowle. Wiesbaden: Reichert Verlag.

Fejfer, J. 1997. The Ince Blundell Collection of Classical Sculpture. Liverpool: Liverpool University Press.

Fittschen, K. 1977. Katalog der antiken Skulpturen in Schloss Erbach. Deutsches Archäologisches Institut. Berlin: Mann.

Fittschen, K. 1986. "I ritratti di Germanico." In Germanico. La persona, la personalità, il personaggio nel bimillenario dalla nascita. Atti del convegno, Macerata-Perugia, 9-11 maggio 1986, Roma, 1986, ed. G. Bonamente and M. Segolomi, 205-18. Rome: G. Bretschneider.

Fittschen, K. 2006. Die Bildnisgalerie in Herrenhausen bei Hannover. Zur Rezeptions- und Sammlungsgeschichte antiker Porträts. Abhandlungen der Akademie der Wissenschaften. Göttingen: Vandenhoeck and Ruprecht.

Fittschen, K., and Zanker, P. 1985. Katalog der Römischen Porträts in den Capitolinischen Museen und den anderen kommunalen Sammlungen der Stadt Rom. Vol. 1 Mainz: P. von Zabern.

Giroire, C., and D. Roger. 2007. Roman Art from the Louvre. New York: American Federation of Arts. Hawkes, C., and P. Crummy. 1995. Camulodunum 2. Colchester: Colchester Archaeological Trust.

Henig, M. 2002. The Heirs of King Verica: Culture and Politics in Roman Britain. Stroud: Tempus.

Heron-Allen, E. 1915. “The Bosham head of Germanicus (?)." Sussex Archaeological Collections 57: 217. Johansen, F. 1994. Catalogue of Roman Portraits 1: Ny Carlsberg Glyptotek. Copenhagen: Bianco Luno.

Kenny, J. 2004. "Bosham: The facts and the fiction." Past Matters. Chichester: Chichester District Council.

Kleiner, D. 1992. Roman Sculpture. New Haven: Yale University Press.

Langhorne, J. 2014. "The other Bosham head." Bosham Life (Feb.): 8-9.

MacDermott, K. 1910. “Roman remains at Bosham.” Sussex Archaeological Collections 53: 272.

Michaelis, A. 1882. Ancient Marbles in Great Britain. Cambridge: Cambridge University Press.

Mitchell, H. 1866. "On the early traditions of Bosham." Sussex Archaeological Collections 18: 6.

Padgett, J. 2001. Roman Sculpture in the Art Museum, Princeton University. Princeton: Princeton University Press.

Painter, K. 1965. "A Roman marble head from Sussex." AntJ 45: 178-82.

Painter, K. 1971. "Roman sculpture from Hampshire, Somerset, Wiltshire, and Sussex." BMQ 36, no. 1: 30-37. 


\section{Two portraits of Agrippa Postumus in the British Museum}

Pollini, J. 1987. The Portraiture of Gaius and Lucius Caesar. New York: Fordham University Press.

Pollini, J. 2012. From Republic to Empire: Rhetoric, Religion, and Power in the Visual Culture of Ancient Rome. Norman: Oklahoma University Press.

Pollini, J. 2020. "The image of Caligula: Myth and reality." In New Studies on the Portrait of Caligula in the Virginia Museum of Fine Arts, ed. E. Varner, 70-90. Leiden: Brill.

Raeder, J. 2000. Die antiken Skulpturen in Petworth House (West Sussex). Mainz: Philipp von Zabern.

Rose, C. 1997. Dynastic Commemoration and Imperial Portraiture in the Julio-Claudian Period. Cambridge: Cambridge University Press.

Russell, M. 2006. Roman Sussex. Stroud: Tempus.

Russell, M. 2013. "A near life-size, togate bust from Chichester, West Sussex." Britannia 44: 264-70.

Russell, M. 2016. "The Pulborough head: A mid-3rd-century Roman stone portrait from West Sussex." Sussex Archaeological Collections 154: 113-21.

Russell, M. 2019. "Farewell two arms: A Roman bronze body part from Halnaker, West Sussex." Sussex Archaeological Collections 157: 125-32.

Russell, M., and H. Manley. 2013. "Finding Nero: Shining a new light on Romano-British sculpture." IntArch 32. https://doi.org/10.11141/ia.32.5.

Russell, M., and H. Manley. 2015. "Trajan places: Establishing identity and context for the Bosham and Hawkshaw heads." Britannia 46: 151-69.

Scott, J. 2003. The Pleasures of Antiquity: British Collectors of Greece and Rome. New Haven: Yale University Press.

Smith, A. 1892. A Catalogue of Sculpture in the Department of Greek and Roman Antiquities. Vol. 3. London: British Museum.

Soffe, G. and Henig, M. 1999. "Roman marble and bronze sculpture in the Kingdom of Togidubnus." Bulletin for the Association of Roman Archaeology 8: 8-10.

Stewart, P. 2020. A Catalogue of the Sculpture Collection at Wilton House. Oxford: Archeopress.

Sumi, A. 2009. "Monuments and memory: The Aedes Castoris in the formation of Augustan ideology." CQ 59: 167-86.

Thompson, J. 2015. Wonderful Things: A History of Egyptology. Vol. 1, From Antiquity to 1881. Cairo: The American University in Cairo Press.

Toynbee, J. 1962. Art in Roman Britain. London: Phaidon.

Toynbee, J. 1964. Art in Britain under the Romans. Oxford: Clarendon.

Varner, E. 2004. Mutilation and Transformation: Damnatio memoriae and Roman Imperial Portraiture. Leiden: Brill.

Vickers, M. 2006. The Arundel and Pomfret Marbles. Oxford: Ashmolean Museum.

Zanker, P. 1973. Studien zu den Augustus-Porträts. Vol. 1, Der Actium-Typus. Göttingen: Vandenhoeck and Ruprecht.

Zanker, P. 1988. The Power of Images in the Age of Augustus. Ann Arbor: University of Michigan Press. 